\title{
THE IMPLEMENTATION OF REACT STRATEGY COMBINED WITH CONSTRUCTIVISM BASED-MODULE IN IMPROVING STUDENTS' CRITICAL THINKING SKILLS, LEARNING OUTCOMES AND SELF- EFFICACY
}

\author{
Muhibbuddin $^{1^{*}}$, Wardatul Hayuni ${ }^{2}$, Andi Ulfa Tenri Pada ${ }^{3}$ \\ ${ }^{1}$ Dr, Syiah Kuala University, Banda Aceh, Indonesia, muhibbuddin@unsyiah.ac.id \\ 22Syiah Kuala University, Banda Aceh, Indonesia, wardatulhayuni95@gmail.com \\ ${ }^{3}$ Dr., Syiah Kuala University, Banda Aceh, Indonesia, andiulfa.usk@gmail.com \\ ${ }^{*}$ Corresponding Author
}

\begin{abstract}
Critical thinking skills play an important role in improving students' learning outcomes. The development of critical thinking skills and learning outcomes are also influenced by self-efficacy. Studies show that the students' critical thinking skills and learning outcomes have not been maximized due to low in students' selfefficacy. Therefore, the innovation in learning process is needed to tackle these problems. This study aims to determine whether the application of relating, experiencing, applying, cooperating, transferring (REACT) strategies combined with constructivism-based modules can improve the students' critical thinking skills, learning outcomes and self-efficacy. This study employed the experimental method with a pretest-posttest control group design. The research subjects were 105 students who were divided into two groups, namely the experimental group which consist of 54 students and the control group consist of 51 students. This research was conducted in the even semester of the 2019/2020 school year at Nagan Raya High School, Aceh, Indonesia. The parameters which measured here are the critical thinking skills, the learning outcomes and self-efficacy. Data on critical thinking skills and learning outcomes were analyzed using parametric statistical tests, and data for self-efficacy were analyzed using interval successive method (MSI). Data for the correlation among students' self-efficacy, critical thinking skills and learning outcomes were analyzed through correlation and regression analysis. The results indicate that the application of the REACT strategy combined with constructivism-based modules can improve students' critical thinking skills, learning outcomes and self-efficacy. Self-efficacy contributes to improve the students' critical thinking skills and learning outcomes.
\end{abstract}

Keywords: REACT, Critical Thinking Skills, Learning Outcomes, Self-Efficacy.

\section{INTRODUCTION}

Critical thinking skills play an important role in improving student learning outcomes and are needed in the application of biological sciences. Critical thinking skills allow students to gain a more complex understanding of the information presented. Critical thinking skills are described as the process of using high-level skills to understand problems, analyze, synthesize, and logically assess ideas (Reinstein and Bayou, 1997).

The results of the interview with the Biology teacher at SMAN Nagan Raya showed the students' difficulties in understanding the material, one of which was the excretion system material. This material is broad, complex, and requires analysis (one of which is the process of urine formation). The excretion system material is included in the National Examination with a score below the average. Puspendik data in Nagan Raya Regency shows the average value for this material is 42.15 in 2017 and is below the provincial and national levels (Anonymous, 2019). 
Not achieving the excretion system material in the learning process, especially critical thinking skills, has an impact on learning outcomes. The percentage of students who can achieve the minimum completeness criteria $(\mathrm{KKM})$ is only around $30 \%$, and the remaining $70 \%$ does not.

The development of critical thinking skills and learning outcomes is also influenced by self-efficacy which is included in the affective domain (Hoffman \& Gregory, 2009). Self-efficacy is a student's belief in doing certain tasks (Pajares, 1996; Sawtelle et al., 2012; Tierney, 2002). Students with low self-efficacy will avoid assignments given by the teacher, while students with high self-efficacy will face learning tasks and have high enthusiasm in the learning process, thus creating an effective learning process (Zimmerman, 2000).

The development of critical thinking skills, learning outcomes, and self-efficacy requires constructivism based strategies and modules. This study combines the REACT module and strategy. REACT is a contextual learning strategy that provides space in building knowledge related to real contexts. According to Crawford (2001), the syntax of this strategy includes relating, experiencing, applying, cooperating, and transferring.

Several studies on learning with the application of the REACT strategy (Relating, Experiencing, Applying, Cooperating, Transferring) have been conducted by Jelatu \& Ardana (2018), Ultay \& Calik (2011), Karsli \& Yigit (2017), Bilgin et al. (2017), and Utami (2016). These studies only reveal the effect of using the REACT strategy on learning outcomes. On the other hand, studies that examine critical thinking skills, self-efficacy, and the application of modules are still very limited. Based on this, this study was conducted to determine the effect of implementing a combination of REACT strategies and constructivism-based modules on improving students' critical thinking skills, learning outcomes, and self-efficacy.

\section{RESEARCH METHODOLOGY}

This study used an experimental method with a pretest-posttest control group design. Table-1 shows the study design (Gall et al., 2003). The research subjects were 105 students who were grouped into experimental and control groups. The experimental group consisted of 52 students, while the control group consisted of 50 students who were randomly selected. The experimental group got a qualification in the form of using a combination of REACT strategies and constructivism-based modules, while the control group still used conventional learning strategies and textbooks. This research was conducted in the even semester of the 2019/2020 school year at Senior High Schools in Banda Aceh City, Indonesia. The parameters measured in this study are critical thinking skills, learning outcomes, and self-efficacy. Data on critical thinking skills and learning outcomes were obtained through pretest and posttest. This study used a test instrument consisting of 50 multiple choice objective tests. Self-efficacy data were obtained from posttest data using a 30 statement questionnaire instrument.

Table-1. Pretest-Posttest Non-Equivalent Control Group Design

\begin{tabular}{|c|c|c|c|c|}
\hline Sample & Groups & Pretest & Treatment & Posttest \\
\hline Random & Experiment & $\mathrm{O}_{1}$ & $\mathrm{P}_{1}$ & $\mathrm{O}_{2}$ \\
\hline Random & Control & $\mathrm{O}_{3}$ & - & $\mathrm{O}_{4}$ \\
\hline
\end{tabular}

Information:

\begin{tabular}{|l|l|}
\hline $\mathrm{O}_{1}$ & $:$ The pretest (before treatment) scores of the experimental group \\
\hline $\mathrm{O}_{2}$ & $:$ The posttest (after treatment) scores of the experimental group \\
\hline $\mathrm{O}_{3}$ & $:$ The pretest (before treatment) scores of the control group \\
\hline $\mathrm{O}_{4}$ & $:$ The posttest (after treatment) scores of the control group \\
\hline $\mathrm{P}_{1}$ & $:$ Treatment group with constructivism module-based REACT learning \\
\hline
\end{tabular}

\section{DATA AND ANALYSIS}

Data learning outcomes and critical thinking skills were analyzed using parametric statistical tests using independent sample t-test, while self-efficacy was analyzed using the successive interval (MSI) method. The correlation between self-efficacy and critical thinking skills and learning outcomes is known through 
correlation and regression analysis.

\section{RESULT AND DISCUSSION}

\subsection{Critical Thinking Skill}

Figure-1 shows the data on the initial ability of students' critical thinking skills in the experimental and control group. The pretest mean of the control group was 31.50, while the experimental group was 32.30. The results of the difference test of the pretest mean between the experimental group and the control group (Table-2) did not show a significant difference. After treatment, the post-test mean increased (the experimental group was 77.29, and the control group was 62.73).



Figure-1 The mean of students' critical thinking skills in the experimental group and the control group

Tabel-2 Difference Test of the Mean of Pretest and N-gain

\begin{tabular}{|c|c|c|c|c|c|c|}
\hline \multirow{2}{*}{ Mean } & \multicolumn{2}{|c|}{ Groups } & \multicolumn{2}{|c|}{ Normality } & \multirow{2}{*}{ Homogeneous } & \multirow{2}{*}{ Significance } \\
\hline & Experiment & Control & Experiment & Control & & \\
\hline Pretest & 32,30 & 31,50 & $\begin{array}{c}X_{\text {count }}^{2}< \\
X_{\text {table }}^{2} \\
(6,66< \\
9,48) \\
\text { Normal }\end{array}$ & $\begin{array}{c}X_{\text {count }}^{2}<X_{\text {table }}^{2} \\
(6,29<9,48) \\
\text { Normal }\end{array}$ & $\begin{array}{c}F_{\text {count }}<F_{\text {table }} \\
(1,22<1,59) \\
\text { Homogeneous }\end{array}$ & $\begin{array}{c}\mathrm{t}_{\text {count }}<\mathrm{t}_{\text {table }} \\
(0,44<1,98) \\
\text { Not significantly } \\
\text { different }\end{array}$ \\
\hline N-Gain & 74,30 & 67,50 & $\begin{array}{c}X_{\text {count }}^{2}<X^{2} \\
\text { table } \\
(2,86< \\
9,48) \\
\text { Normal }\end{array}$ & $\begin{array}{c}X^{2}{ }_{\text {count }}<X^{2} \text { table } \\
(3,45<9,48) \\
\text { Normal }\end{array}$ & $\begin{array}{c}\mathrm{F}_{\text {count }}<\mathrm{F}_{\text {table }} \\
(1,18<1,59) \\
\text { Homogeneous }\end{array}$ & $\begin{array}{c}t_{\text {count }} \geq t_{\text {table }} \\
(2,26 \geq 1,98) \\
\text { Significantly } \\
\text { different }\end{array}$ \\
\hline
\end{tabular}

\section{Description:}

$\left.{ }^{*}\right)=$ Chi Square Test (Normal, score $X_{\text {count }}<X_{\text {table, }}^{2} \alpha=0,05$ )

$\left.{ }^{* *}\right)=F$-test $\left(\right.$ Homogenous, score $\left.F_{\text {count }}<F_{\text {table }}, \alpha=0,05\right)$

The difference in critical thinking skills between the experimental group and the control group was caused by differences in learning strategies between the two groups. The combination of REACT learning strategies and constructivism-based modules (learning strategies related to experience and application of understanding in various contexts) allows students to be active in discovering the concepts being learned. The achievement of critical thinking skills in the experimental group which was taught with the REACT strategy increased student activeness and responsiveness. The REACT strategy trains students to develop 
the ability to directly connect more concrete abstract concepts, apply the knowledge and skills they have with everyday problems related to the material that has been taught. This strategy also teaches students to work together in groups and transfer what is obtained in the learning process (Ultay and Calik, 2012).

\subsection{Learning Outcomes}

Figure-2 shows the initial ability data for the experimental and control group learning outcomes. The pretest of the mean of the control group was 38.81 while the experimental group was 40.17 . The difference test of the pretest mean between the experimental group and the control group (Table-3) did not show a significant difference. The mean of the post-test increased after getting treatment (the experimental group was 71.00 and control group was 81.22).

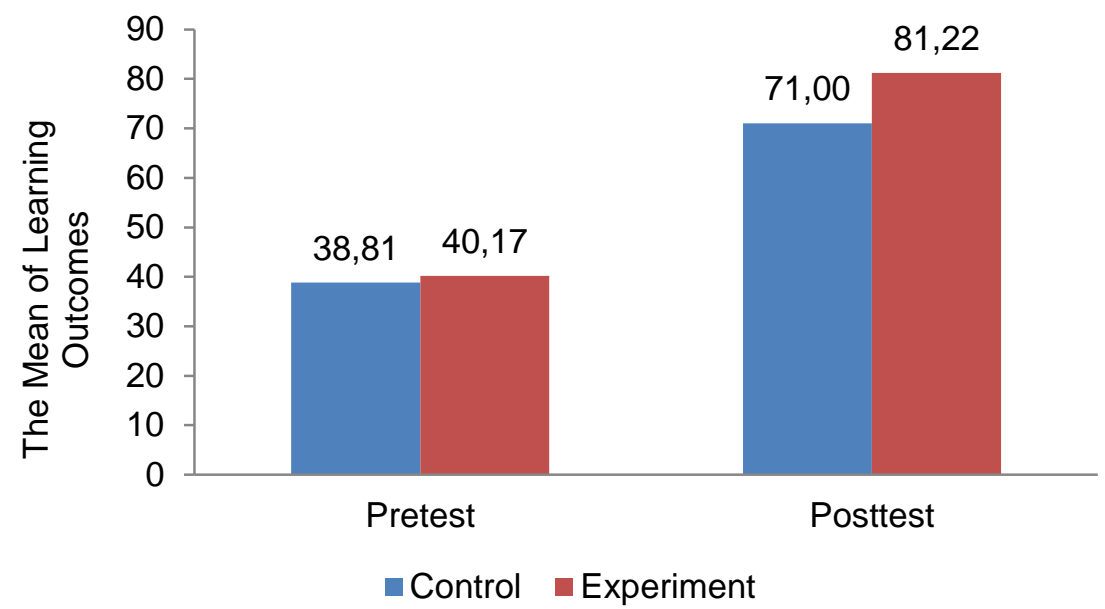

Figure-2. The mean of student learning outcomes in the experimental group and the control group

Table-3. Difference Test of the Mean of Pretest and N-gain

\begin{tabular}{|c|c|c|c|c|c|c|}
\hline \multirow{2}{*}{ Mean } & \multicolumn{2}{|c|}{ Group } & \multicolumn{2}{|c|}{ Normality } & \multirow{2}{*}{ Homogeneous } & \multirow{2}{*}{ Significance } \\
\hline & Experiment & Control & Experiment & Control & & \\
\hline Pretest & 40,17 & 38,81 & $\begin{array}{c}X_{\text {count }}^{2}< \\
X_{\text {table }}^{2} \\
(5,20<9,48) \\
\text { Normal }\end{array}$ & $\begin{array}{c}X_{\text {count }}^{2}< \\
X_{\text {table }}^{2} \\
(2,74<9,48) \\
\text { Normal }\end{array}$ & $\begin{array}{c}F_{\text {count }}<\mathrm{F}_{\text {table }} \\
(1,36<1,59) \\
\text { Homogeneous }\end{array}$ & $\begin{array}{c}\mathrm{t}_{\text {count }}<\mathrm{t}_{\text {table }} \\
(0,81<1,98) \\
\text { Not Significantly } \\
\text { Different }\end{array}$ \\
\hline N-Gain & 72,20 & 65,50 & $\begin{array}{c}X^{2} \text { count }< \\
X_{\text {table }}^{2} \\
(5,14<9,48) \\
\text { Normal }\end{array}$ & $\begin{array}{c}X^{2}{ }_{\text {count }}< \\
X_{\text {table }}^{2} \\
(6,34<9,48) \\
\text { Normal }\end{array}$ & $\begin{array}{c}F_{\text {count }}<F_{\text {table }} \\
(1,07<1,59) \\
\text { Homogeneous }\end{array}$ & $\begin{array}{c}t_{\text {count }} \geq t_{\text {table }} \\
(2,44 \geq 1,98) \\
\text { Significantly } \\
\text { different }\end{array}$ \\
\hline
\end{tabular}

\section{Description:}

$\left.{ }^{*}\right) \quad=$ Chi Square Test (Normal, score $X^{2}{ }_{\text {count }}<X_{\text {table, }} \alpha=0,05$ )

${ }^{* *}$ ) $=\mathrm{F}$-test (Homogeneous, score $\mathrm{F}_{\text {count }}<\mathrm{F}_{\text {table }}, \alpha=0,05$ )

The research data shows differences in learning outcomes between the experimental group and the control group. The experimental group that implements the REACT learning strategy emphasizes students to build knowledge and meaningful learning, independent, creative, and active so that the teacher only acts as a facilitator. It means that the teacher does not provide overall knowledge but only stimulates students to discover concepts through modules so that they can communicate their knowledge to other students.

REACT increases student activity in exploring questions, discussions, presentations, and practicum of urine test results. This is due to an increase in understanding of the initial concepts at the relating stage and constructivism modules which can be used as a reference source in learning. 
The research results of Farid and Nurhayati (2013) also show that learning with the REACT strategy has an effect of $20.25 \%$ on learning outcomes compared to conventional learning. Ultay (2012) states that REACT increase student enthusiasm, learning is more fun, increases learning effectiveness, and student involvement in the learning process due to increased student activity.

\subsection{Self-Efficacy}

Figure-3 shows the mean score of self-efficacy in the experimental group is 89 (very good) and the control group is 79 (good). Another step in the REACT strategy is Relating. It means that students logically relate known facts to conclude by relating common experiences. Relating is one of the main elements of building student self-efficacy. Putri \& Santoso (2015) state that the REACT learning strategy is effective in developing student self-efficacy

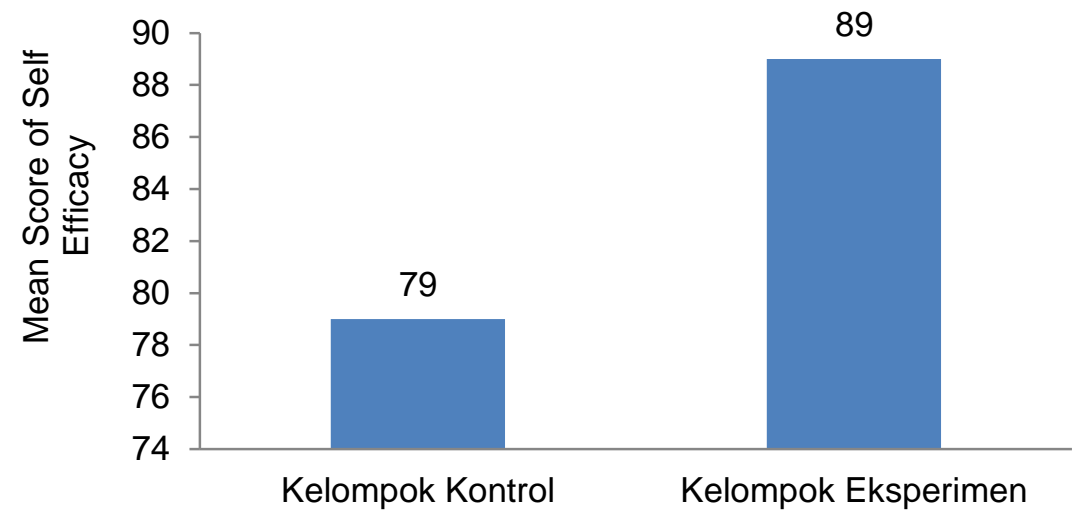

Figure-3. The mean score of students' self-efficacy in the experimental and the control groups

Learning in the experimental group requires students to have a self-efficacy attitude because they apply the REACT strategy in the learning process. The process of implementing the REACT strategy has a cooperating step (cooperation between groups). This stage can increase students' self-efficacy because in the cooperating stage there is cooperation (discussion) and continued with the transferring stage (communicating the results of the discussion) so that it affects the development of student self-efficacy. This strategy encourages students to analyze to solve problems. Reivich \& Shatte (2002) stated that individuals with high self-efficacy will be committed to solving problems and will not give up when the strategies used are difficult or unsuccessful.

The combination of REACT strategy and constructivism-based modules is effective in increasing students' self-efficacy and academic abilities. Bong \& Skaalvik (2003) and Omrod (2008) state that self-efficacy can improve cognitive processes, attention, and coordination and elaborate on students' abilities.

\subsection{Correlation between Self Efficacy and Critical Thinking Skills}

The results of data analysis showed a positive and significant relationship (Table 4).

Table-4. The Results of the Correlation between Self Efficacy and Critical Thinking Skills

\begin{tabular}{|c|c|c|c|}
\hline Correlation (r) & $\begin{array}{c}\text { The coefficient of } \\
\text { determination }\end{array}$ & Test of significance $(\mathbf{r})$ & Information \\
\hline $\mathbf{0 , 4 4}$ & $\mathbf{0 , 1 9}$ & $\begin{array}{c}3,46>2,00 \\
\mathrm{t}_{\text {count }}>\mathrm{t}_{\text {tabel }}\end{array}$ & Significance \\
\hline
\end{tabular}

The results of the correlation between self-efficacy and critical thinking skills showed a positive correlation with moderate interpretation $(r=0.44)$ and a determination coefficient of 0.19 . It shows that self-efficacy has an influence of $19 \%$ on critical thinking skills, while the remaining $81 \%$ is influenced by other factors not examined in this study.

The regression results between self-efficacy and critical thinking skills (Figure-4) indicate that self-efficacy contributes to critical thinking skills; the higher the self-efficacy, the higher the critical thinking skills ( $y=7.68$ $+0.77 x$.) 


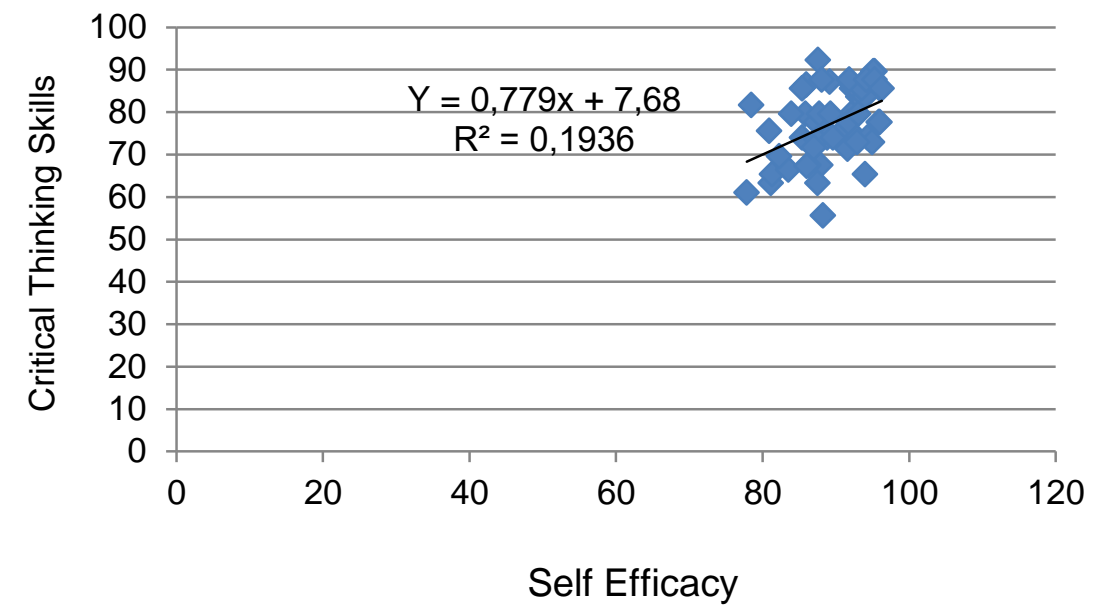

Figure-4. Regression between Self Efficacy and Critical Thinking Skills

Self-efficacy has a positive and significant effect on students' critical thinking skills (Table 4). Self-efficacy increases self-confidence, activeness, and critical thinking in each group activity and shows an increase in academic achievement or activity Students with high self-efficacy have better critical thinking skills than students with low self-efficacy. High self-efficacy will make it easier for students to understand concepts and have a big influence on the decision-making process (Block \& Russel, 2012).

\subsection{Correlation between Self Efficacy and Learning Outcomes}

The results of data analysis showed a positive and significant relationship (Table 5).

Table-5. The results of correlation between Self Efficacy and Learning Outcomes

\begin{tabular}{|c|c|c|c|}
\hline Correlation (r) & $\begin{array}{c}\text { The coefficient of } \\
\text { determination }\end{array}$ & Test of significance (r) & Information \\
\hline 0,47 & 0,22 & $\begin{array}{l}3,39>2,00 \\
T_{\text {count }}>t_{\text {table }}\end{array}$ & Significance \\
\hline
\end{tabular}

The results of the correlation between self-efficacy and learning outcomes showed a positive correlation with moderate interpretation $(r=0.47)$ and a determination coefficient of 0.22 . It shows that self-efficacy affects $22 \%$ of learning outcomes, while the remaining $78 \%$ is influenced by other factors not examined in this study.

The results of the regression test (Figure-5) indicate that self-efficacy contributes to student learning outcomes; the higher the self-efficacy, the higher the learning outcomes $(Y=11,325+0.783 x)$.

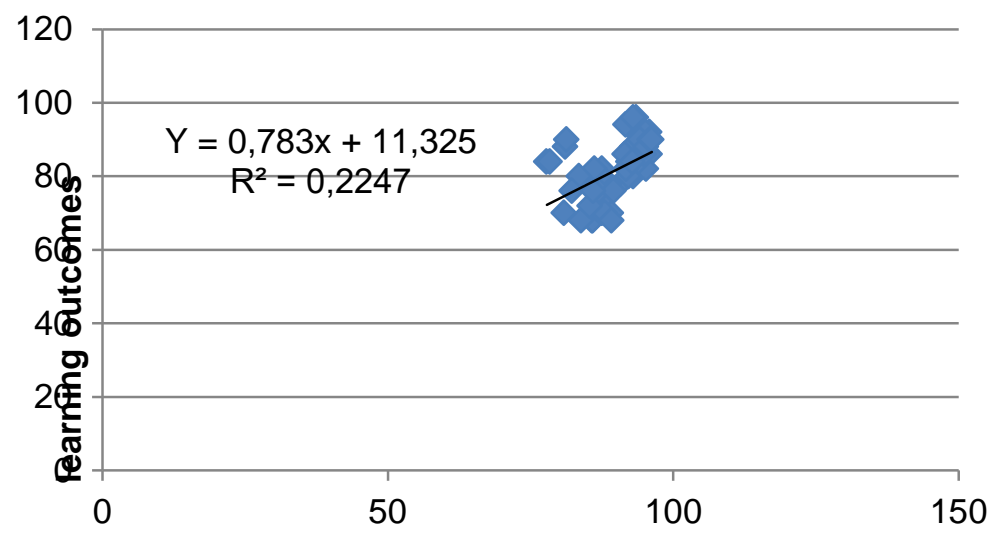

Self Efficacy

Figure-5. Regression between Self Efficacy and Learning Outcomes 
The application of a combination of the REACT strategy and constructivism-based modules on the excretion system material contributes significantly to self-efficacy and student learning outcomes. The application of this strategy can increase self-efficacy and student learning outcomes. According to Motlagh et al. (2011), self-efficacy is another factor that affects academic achievement which has an impact on learning outcomes, so that self-efficacy is one of the factors that must be emphasized in education.

Self-efficacy is one of the factors that determine the quality of achievement or good learning outcomes. Selfefficacy affects students' choice of activities. Students with low self-efficacy will avoid learning tasks (especially those that challenge ones), while students with high self-efficacy will be challenged by learning tasks (Schunk \& Meece, 2005). This shows that self-efficacy affects learning outcomes; the higher the selfefficacy means, the higher the learning achievement, and vice versa (Handayani, 2011).

\section{CONCLUSION}

The results showed differences in critical thinking skills, learning outcomes, and self-efficacy between students in the experimental group and the control group. Self-efficacy contributes to improving critical thinking skills and student learning outcomes.

\section{REFERENCE LIST}

Anonymous. (2019). Laporan Hasil Ujian Nasional. Tersedia di: https://hasilun.puspendik. kemdikbud.go.id. (Accessed on 15 Desember 2019).

Bilgin, A.K.; Yurukel, F.N.; Demircioglu. \& Yigit, N. (2017). The Effect of a Developed REACT Strategy on the Conceptual Understanding of Students: "Particulate Nature of Matter". Journal of Turkish Science Education, 14(2):65-81.

Block, B.A. \& Russel, W. (2012). Teaching Students to Think Critically About Fitness and Wellness Choices. Journal of Physical Education, Recreation and Dance, 83(7):46.52.

Bong, M. \& Skaalvik, E.M. (2003). Academy Self Concept and Self Efficacy: How Different are They Really. Education Psychology Review, 15(1):1-40.

Crawford, M. L. (2001). Teaching Contextually: Research, Rationale, And Techniques for Improving Student Motivation and Achievement in Mathematics and Science. Waco, Texas, USA: CORD CCI Publishing, Ic.

Farid, A. \& Nurhayati, S. (2013). Pengaruh Penerapan Strategi REACT Terhadap Learning outcomes Kimia Siswa Kelas XI. Chemistry in Education, 3(1):36-42.

Gall, M. D.; Gall,J.P \& Brog, W.R. 2003. Educational Research an Introduction Boston: Pearson Education Inc.

Handayani, I. (2011). Penggunaan Model Method dalam Pembelajaran Pecahan Sebagai Upaya Meningkatkan Kemampuan Pemecahan masalah Matematik dan Self Efficacy Siswa Sekolah Dasar. Tesis. Bandung: Universitas Pendidikan Indonesia.

Hoffman, B. \& Gregory, S. (2009). The Influence of Self Efficacy and Working Memory Capacityon ProblemSolving Efficiency. Learning and Individual Differences, 19(21):91-100.

Jelatu, S.S. \& Ardana, I.M. (2018). Effect of GeoGebra-Aided REACT Strategy on Understanding of Geometry Concepts. International Journal of Instruction, 11(2): 325-336.

Karsli, F. \& Yigit, M. (2017) Effectiveness of the REACT Strategy on 12th Grade Students' Understanding of the Alkenes Concept. Research in Science \& Technological Education, 35(3): 274-291. Tersedia di: https://www.tandfonline.com/doi/full/10.1080/ 02635143.2017.1295369?scroll=top\&needAccess=true (Accessed on 28 Oktober 2019).

Motlagh, S.E.; Amrai, K.; Yazdani, M.J.; Altaib, A.H. \& Souri, H. (2011). The Relationship Between SelfEfficacy and Academic Achievement in High School Students. Procedia-Social and Behavioral Sciences, 15(1):765-768.

Omrod, J. E. (2008). Psikologi Pendidikan Jilid 2. Jakarta: Erlangga.

Pajares, F. (1996). Self Efficacy Beliefs In Academic Settings. Review Of Educational Research, 66(4):543- 
578.

Putri, I.R. \& Santoso, R.H. (2015). Keefektifan Strategi REACT ditinjau dari Prestasi Belajar, Kemampuan Penyelesaian Masalah, Koneksi Matematis dan Self Efficacy. Jurnal Riset Pendidikan Matematika, 2(2):262-272.

Reinstein, A. \& Bayou, M.E. (1997) Critical Thinking in Accounting Education: Process, Skills and Applications. Managerial Auditing Journal, 12(1956):336-342.

Reivich, K. \& Shatte, A. (2002). The Resilience Factor: 7 Essential Skill for Overcoming Life's Inevitable Obstacle. New York: Broadway Book.

Sawtelle, V.; Brewe, E. \& Kramer, L.H. (2012). Exploring the Relationship Between Self Efficacy and Retention in Introductory Physic. Journal of research in science teaching, 49(9):1096-1121.

Schunk, D.H. \& Meece, J.L. (2005). Self-Efficacy Development in Adolescences, In Self Efficacy Beliefs of Adolescences by Information Age Publishing.

Tierney, F. (2002). Creative Self-Efficacy: Its Potential Antecedents and Relationship to Creative Performance. Academy of Management Journal, 45:1137-1148.

Ultay, E. (2012). Implementing REACT Strategy in a Context-Based Physics Group: Impulse and Momentum Example. Energy Education Science and Technology Part B: Social and Educational Studies, 4(1):233-240.

Ultay, N. \& Calik, M. (2011). Distinguishing 5E Model from REACT Strategy: An Example of Acids and Bases Topic. Necabity Faculty of Education Electronic Journal of Science and Mathematics Education, 5(2):199-200.

Utami, S. U. (2016). REACT (Relating, Experiencing, Applying, Cooperating, Transferring) Strategy to Develop Geography Skills. Journal of Education and Practice, 7(17):100-104.

Zimmerman. (2000). Self-Efficacy an Essential Motive to Learn. Contemporary Educational Phycology. 25:82-92 